\title{
CONSTRUÇÃO DA SEDE PARA OS CURSOS DE ENFERMAGEM E TERAPIA OCUPACIONAL : UMA CONQUISTA COLETIVA
}

Marilene Loewen Wall ${ }^{1}$

Em 2002, o Conselho do Setor de Ciências da Saúde da Universidade Federal do Paraná requereu informações sobre as necessidades relativas às instalações de estrutura física para a Enfermagem UFPR. As solicitações, aprovadas e incluídas na lista de prioridades do Setor, reiteravam as demandas de área física de trinta anos de existência do Curso.

No ano de 2003, o curso de Terapia Ocupacional se agregou ao projeto para o atendimento das necessidades comuns, sendo instituída uma Comissão conjunta, responsável pela coordenação de um Projeto Arquitetônico da sede. A Comissão composta pelos chefes de departamento, coordenadores e professores dos respectivos cursos, em conjunto realizou estudos para que houvesse condições adequadas para o desenvolvimento do ensino de graduação e pós-graduação, pesquisa e extensão.

A partir de 2004, a Comissão juntamente com a Pró-Reitoria de Administração otimizaram o levantamento topográfico do terreno destinado à construção, no Campus Botânico, e o desenvolvimento do projeto arquitetônico, o qual foi concluído e aprovado pelos Departamentos e Coordenações de Enfermagem e Terapia Ocupacional, Pós-Graduação em Enfermagem bem como pela Direção do Setor de Ciências da Saúde. A Reitoria comprometeu-se em disponibilizar parte equivalente de recursos que fossem conseguidos pelos Cursos, incentivando estes à buscá-los por meio de emendas parlamentares. Dessa forma, ainda em 2004, a Coordenação do Curso de Terapia Ocupacional agilizou projeto de emenda parlamentar ao Senado, solicitando verba destinada à construção da Clínica de Terapia Ocupacional. E o Departamento de Enfermagem disponibilizou um equivalente a esta Emenda, transferido pelo Programa de Residência Multiprofissional em Saúde da Família (2002-2004), à época coordenado e desenvolvido pelos docentes do citado Departamento, para compor o fundo e, assim, dar início à construção.

Em 8 de julho de 2005, foi realizada por solicitação do então Diretor do Setor de Ciências da Saúde, Prof. Dr. Rogério Andrade Mulinari, reunião da Comissão com o Magnífico Reitor, Prof. Dr. Carlos Augusto Moreira Júnior, que autorizou as providências para o início da primeira etapa da obra, liberando o valor equivalente ao já arrecadado pelos Cursos.

Em agosto de 2006, houve modificações no projeto, exigidas pela Comissão do Plano Diretor, incluindo a verticalização da construção com vistas ao melhor aproveitamento da área, prevendo cinco andares a serem construídos em três etapas.

O início das obras deu-se em janeiro de 2007, ano em que houve a possibilidade de adesão ao Programa de Apoio ao Plano de Reestruturação e Expansão das Universidades Federais - REUNI, no qual a Pós-Graduação em Enfermagem ampliou as vagas no mestrado acadêmico e o Curso de Terapia Ocupacional expandiu as vagas na graduação, criando uma turma no período noturno.

No dia 13 de dezembro de 2010, foi inaugurada a estrutura principal do prédio. Para a Enfermagem UFPR, este espaço, conquistado com muito empenho, significa uma vitória coletiva, fruto da união de pessoas que fazem parte de cursos distintos, porém com o mesmo objetivo, ou seja, o de realizar ações de ensino, pesquisa e extensão, comprometidas na construção da vida e da saúde.

Muitas foram as mãos que colaboraram e participaram desta história, entre elas as citadas e outras tantas, como nossas professoras já aposentadas.

${ }^{1}$ Enfermeira. Doutora em Enfermagem. Chefe do Departamento de Enfermagem da Universidade Federal do Paraná-UFPR. Professora do Curso e do Programa de Pós-Graduação em Enfermagem da UFPR. 


\section{CONSTRUCTION OF A DEPARTMENT BUILDING FOR NURSING COURSES AND OCCUPATIONAL THERAPY: A GROUP ACHIEVEMENT.}

Marilene Loewen Wall ${ }^{1}$

In 2002, the Health Sciences Department's department counsel at the Federal University of Paraná (UFPR) solicited information about the needs related to a physical structure for the UFPR's Nursing Department. The requirements, approved and included on the department's priority list, reiterated the request for a physical space that has been made over the thirty years the course has been running.

In 2003 the Occupational Therapy course joined the project to meet its common needs, a commission being set up to coordinate the architectural project of the joint department building. Made up of department heads, coordinators and professors from the respective courses, the commission carried out studies to ensure that there would be appropriate conditions for the development of teaching - at undergraduate, post-graduate, research and extension levels.

From 2004 onward, the commission, along with the Pro-Rectorate of Administration, optimized the topographical levelling of the land to be built on in the Botanical Campus, and the development of the architectural project, which was concluded and approved by the departments and the coordinators of Nursing and Occupational Therapy, the Nursing Post-Graduate course as well as by the managers of the Department of Health Sciences. The Rectorate undertook to allocate funds equivalent to that which the departments could raise, incentivizing these to seek funds from the government. In this way, still in 2004, the Coordination of the Occupational Therapy course presented a parliamentary amendment to the Senate, requesting funds to be used for the construction of an Occupational Therapy Clinic. Furthermore, the Nursing Department made available an equivalent to this amendment, transferred by the Program for Multiprofessional Residency in Family Health (2002 -2004), at that time coordinated and developed by teachers from that department, to set the foundations and in this way to start the construction process.

On the 8th of July 2005, at the request of the then Head of Health Sciences department, Professor Dr. Rogério Andrade Mulinari, a meeting of the commission was held with the Rector, Professor Dr. Carlos Moreira Junior, who authorized the resources for the commencement of the first stage of the work, releasing the equivalent to that already raised by the departments.

In August 2006 modifications were made to the project, requested by the Main Plan Commission, including the verticalization of the project with a view to better use of the area. Five stories were to be built, in three stages.

The work started in January 2007, a year in which the possibility arose of adhering to the Program for Support to the Plan for Restructuring and Expanding the Federal Universities (REUNI, in Portuguese), under which the Nursing Post-Graduate course increased the places available in its academic masters' course and the Occupational Therapy department widened its undergraduate intake, creating a night course.

On the 13th of December 2010, the main structure of the building was inaugurated. For the UFPR Nursing Department this space - gained with such assiduity - is a collective victory, the result of the union of people who while belonging to different courses share the same aim; teaching, research and extension courses, aligned with the building of life and health.

Many hands collaborated and participated in this history, including not only those mentioned but also others, such as professors who are now retired.

${ }^{1}$ Nurse. Doctor in Nursing. Director of Nursing Departament of the Federal University of Paraná-UFPR. Professor in the Post Graduate Program in Nursing of the UFPR. 


\section{CONSTRUCCIÓN DE LA SEDE PARA LOS CURSOS DE ENFERMERÍA Y TERAPÉUTICA OCUPACIONAL: UNA CONQUISTA COLECTIVA}

Marilene Loewen Wall ${ }^{1}$

En 2002, el Consejo Sectorial del Sector de Ciencias de la Salud de Universidad Federal de Paraná solicitó informaciones de mejorías de estructura física para las instalaciones del curso de Enfermería de UFPR. Tales solicitaciones, aprobadas e incluidas en la relación de prioridades del Sector, reiteraban las demandas del área física de treinta años de existencia del curso.

En el año de 2003, el curso de Terapéutica Ocupacional se agregó al proyecto para el atendimiento de las necesidades comunes, siendo instituida una Comisión conjunta responsable por la coordinación de un proyecto arquitectónico del centro. La Comisión compuesta por los jefes de departamiento, coordinadores y profesores de los respectivos cursos, en conjunto, realizó estudios, para plantear condiciones adecuadas al desarrollo de la enseñanza de graduación y posgrado, investigación y extensión.

A partir de 2004, la Comisión, juntamente con la Rectoría de Administración, optimizaron el estudio topográfico del terreno destinado a la construcción, en el Campus Botánico, y el desarrollo del proyecto arquitectónico, el cual fue concluido y aprobado por los Departamientos y Coordinaciones de Enfermería y Terapéutica Ocupacional, Posgrado en Enfermería, así como por la Dirección del Sector de Ciencias de la Salud. La Rectoria se comprometió en disponibilizar parte equivalente de recursos logrados por los Cursos, incentivándo la búsqueda por otros por medio de enmiendas parlamentares. Así, aún en 2004, la Coordinación del Curso de Terapéutica ocupacional facilitó el proyecto de enmiendas parlamentar al Senado, solicitando presupuesto destinado a la costrucción de la Clínica de Terapéutica Ocupacional.

Y el Departamiento de Enfermería disponibilizó un equivalente a esta Enmienda, transferido por el Programa de Residencia Multiprofesional en Salud de la Familia (2002-2004), coordinado y desarrollado entonces por los docentes de ese Departamiento, para componer los fondos y, de ese modo, empezar la costrucción. En 8 de julio de 2005, fue realizada por solicitación del entonces Director del Sector de Ciencias de la Salud, Prof. Dr. Rogério Andrade Mulinari, una reunión de la Comisión con el Magnífico Rector, Prof. Dr. Carlos Augusto Moreira Júnior, el cual autorizó las providencias para el principio de la primera etapa de la obra, liberando el valor equivalente a aquel recaudado por los cursos.

En agosto de 2006, hubo cambios en el proyecto, exigidos por la Comisión del Plan Director, incluyendo la verticalización de la costrucción con fines de mejorar el aprovechamiento del área, previendo cinco pisos que serían edificados en tres etapas.

En enero de 2007 las obras empezaron. En mismo año, hubo la posibilidad de adhesión al Programa de Apoyo al Plan de Restructuración y Expansión de las Universidades Federales - REUNI, en el cual el Posgrado en Enfermería amplió las plazas en el mestrado académico y el Curso de Terapéutica Ocupacional expandió las plazas en la graduación, creando una clase en el periodo nocturno.

En el dia 13 de diciembre de 2010, fue inaugurada la estructura principal de la construcción. Para la Enfermería UFPR, este espacio, conquistado con mucho empeño, significa una victoria colectiva, fruto de la unión de personas que hacen parte de cursos distintos, pero con el mismo objetivo, es decir, el de realizar acciones de enseñanza, investigación y extensão, involucradas en la costrucción de la vida y de la salud.

Muchas fueron las manos que ayudaron y participaron de esta historia, entre ellas las mencionadas y otras tantas, como las de nuestras profesoras jubiladas.

${ }^{1}$ Enfermera. Doctora en Enfermeria. Jefe del Departamento de Enfermería de la Universidad Federal de Paraná-UFPR. Profesora en el Programa de Posgrado en Enfermería de la UFPR. 